\title{
SERVICES AS CAPITAL CONTRIBUTIONS: UNDERSTANDING KOVACIK V. REED
}

\author{
ROYCE DE R. BARONDES
}

\begin{abstract}
This essay examines the capital accounting of Kovacik v. Reed, leading authority addressing allocation of losses between a partner who contributed only property and another who contributed only services. Kovacik posits that such parties having agreed to share profits equally have implicitly agreed their contributions were of equal value. This essay shows that such an agreement would not produce the result Kovacik reaches. The Kovacik result is instead produced by the following implausible implicit agreement between the parties: The value of the services provided by the services partner to be treated as a capital contribution equals the amount the partnership loses on a cash basis. The more the firm ultimately loses, the more those services are agreed to be worth.

Prior work by Bainbridge identifies a manifestation of a problem in this context referenced as overinvestment in the financial economics literature. This essay further demonstrates the Kovacik result can create a complementary underinvestment problem.
\end{abstract}

\section{INTRODUCTION}

Kovacik v. Reed ${ }^{1}$ is a staple of the study of partnership law. ${ }^{2}$ It is leading authority addressing allocation of losses between a partner who

\footnotetext{
* Associate Professor, University of Missouri-Columbia School of Law. Copyright $\mathbb{C}$ 2007 Royce de R. Barondes.

This essay is dedicated to my Business Organizations students from 2004 through 2007, who endured oral descriptions of various iterations of the original principles articulated in this essay without the benefit of a cogent written description.

Permission is granted for classroom educational use of this essay prior to its publication in a journal provided that each copy is separately downloaded from, and the essay continues to be available for download at that time at, www.ssm.com.

1315 P.2d 314 (Cal. 1957).

${ }^{2}$ See, e.g., Stephen M. Bainbridge, Contractarianism in the Business Associations Classroom: Kovacik v. Reed and the Allocation of Capital Losses in Service Partnerships, 34 GA. L. REv. 631 (2000) (discussing the author's use of Kovacik in the basic class in Business Associations).
} 
contributed only property and another who contributed only services where the partners' express agreement allocated profits equally. The case holds that in liquidation, losses aggregating less than the property contributed are entirely allocated to the partner who contributed property. ${ }^{3}$ The services partner is not required to make a contribution to share the losses, nor does the services partner receive property in the liquidation. As justification, the Kovacik opinion posits that "the parties have, by their agreement to share equally in profits, agreed that the value of their contributions - the money on the one hand and the labor on the other-were likewise equal."4

Students of the law of business organizations frequently prefer to elide issues of accounting. Perhaps that is a preference for judges as well. The opinion in Kovacik does not actually try to reproduce the parties' capital accounts. The case illustrates why, for judges as well as other students of the law, a focus on accounting details can be crucial: Reducing to accounting numbers the court's verbal formulation of an abstract test yields two incontrovertible observations:

1. The opinion, although purporting to rationalize its outcome in two different ways, in fact-apparently without the knowledge of the opinion's authorarticulates principles that support two different rules.

2. Delving into the capital accounting shows that the outcome is consistent with a hypothetical ex ante bargain that is patently implausible.

This essay serves two purposes. It provides insight into the doctrinal issue addressed by Kovacik - allocation of partnership property on windingup when the partnership lost money and one partner's capital contribution solely comprised services. It also illustrates the importance focusing on numbers can have in understanding case-law construing accounting issues, because that is necessary to illuminate the peculiarity of the Kovacik opinion.

The remainder of this essay develops the following conclusions: the Kovacik opinion at one point posits that "the parties have, by their agreement to share equally in profits, agreed that the value of their contributions ... were likewise equal."5 Part I of this essay shows that such an agreement as to the value of the contributions does not produce the result Kovacik reaches. That Part further shows the Kovacik result is instead produced by the following implicit agreement between the parties: The value of the services provided by the services partner to be treated as a capital contribution equals the amount the partnership loses on a cash basis. The more the firm ultimately loses, the more those services are agreed to be worth. There is not a plausible basis for concluding the parties would have

\footnotetext{
${ }^{3}$ Kovacik, 315 P.2d at 316

${ }^{4}$ Id.

${ }^{5}$ Id.
} 
believed that was the value of the services to be provided by the services partner.

As noted in Part I, Bainbridge has stated it is difficult to ascertain the majoritarian hypothetical bargain-the bargain that a majority of partners would have reached had they expressly negotiated as to the matter. One reason he identifies is that the Kovacik result can create incentives for a services-only partner to cause the partnership to engage in excessive risktaking (similar to the overinvestment phenomenon familiar from financial economics) ${ }^{6}$

This essay, while not disagreeing with that conclusion, demonstrates in Part II that the opposite incentive also may be created. The Kovacik result also may create incentives for a services-only partner to wish the partnership to be more risk-averse than one seeking to maximize the aggregate return to the firm. This further supports Bainbridge's conclusion that the hypothetical bargain in this circumstance is indeterminate.

That Part also identifies another factor complicating identification of the majoritarinan hypothetical bargain. Capital accounting focuses the question on what value should be ascribed to a partner's contribution of services. To frame the hypothetical bargain in terms of that value, reflecting the way capital accounting presents the issue, can substantially alter the conclusion relative to framing the inquiry in terms of how a majority of partners would have wanted to resolve the ultimate issueallocation of the property in liquidation.

Lastly, Part III demonstrates that the problems with the internal inconsistency in Kovacik are not confined to circumstances where the property-contributing partner agrees to contribute a fixed amount of property. That Part demonstrates a similar result can obtain where that partner agrees to fund cash-flow needs up to a specified amount.

\section{ANALYSIS OF KOVACIK $V$. REED}

\section{A. The Outcome in Kovacik; An Introduction to the Capital Accounting}

The pertinent facts and holding of Kovacik $v$. Reed can be easily summarized. Kovacik and Reed formed a partnership to do kitchen remodeling. Reed would provide only services - estimating jobs and overseeing the work. ${ }^{7}$ Kovacik would contribute only cash, ${ }^{8}$ agreeing to provide $\$ 10,000 .^{9}$ The parties agreed to split profits equally, without

\footnotetext{
${ }^{6}$ See infra note 35 and accompanying text.

${ }^{7}$ Kovacik, 315 P.2d at 315.

${ }^{8}$ Id.

${ }^{9} I d$. at 316 . This essay discusses in Part III, infra, the alternative possibility that Kovacik made a promise to contribute cash to the extent required to meet the partnership's cash-flow obligations, up to $\$ 10,000$.
} 
discussing possible losses. ${ }^{10}$ Section 18(a) of the Uniform Partnership Act, which was in effect in California at the time, provides, as a default, that losses follow profits."

The partnership ultimately dissolved after having realized a loss of $\$ 8,680$. $^{12}$ Kovacik received a judgment against Reed for half this amount, ${ }^{13}$ which the California Supreme Court reversed, ${ }^{14}$ noting, "Where ... one partner ... contributes the money capital as against the other's skill and labor, all the cases cited, and which our research has discovered, hold that neither party is liable to the other for contribution for any loss sustained."15

The brief opinion does not detail the timing and amounts of the partnership's cash flows; only the ultimate conclusion-the amount of the loss - is provided. The opinion's recitation of the facts notes only obliquely a crucial element-that Kovacik agreed to invest $\$ 10,000 .^{16}$ Nevertheless, the information provided is sufficient to construct the essentials of the capital accounting.

Sections $18(\mathrm{a})$ and 40 of the U.P.A. provide the statutory language that capital accounting tracks. The partners' capital accounts, which implement the express provisions of the U.P.A., as of the time the partnership is formed, can be depicted as follows ${ }^{17}$ :

Figure 1: Initial Capital Accounts

$\begin{array}{lr}\text { Kovacik } & \$ 10,000 \\ \text { Reed } & 0 \\ \text { Total } & \$ 10,000\end{array}$

The explanation is as follows: we do not know precisely the timing of Kovacik's contribution of cash to the partnership. For ease of exposition, the case will first be analyzed construing Kovacik's undertaking as involving an agreement to contribute $\$ 10,000$. For our purposes, the timing of the cash contributions is not important, just the total amount that he contributed (or, if he did not contribute all he agreed to contribute, the amount he agreed to contribute). As noted above, the opinion is somewhat ambiguous in describing the contribution obligation. ${ }^{18}$ As noted in Part III,

\footnotetext{
${ }^{10} I d$. at 315 .

${ }^{11}$ Section 18 of the U.P.A. was codified in California at that time at Cal. Corporations Code $\S 15018$ (West 1955), repealed, 1996 Cal. Stat. 5905.

${ }^{12}$ See Kovacik, 315 P.2d at 315.

${ }^{13} I d$.

${ }^{14}$ Id. at 317 .

${ }^{15} I d$. at 316 .

${ }^{16}$ See id. at 316 ("[P]laintiff here lost only some $\$ 8,680$ - or somewhat less than the $\$ 10,000$ which he originally proposed and agreed to invest.").

${ }^{17}$ Sections 18 and 40 of the U.P.A. were codified in California at that time at Cal. Corporations Code $\S \S 15018,15040$ (West 1955), repealed, 1996 Cal. Stat. 5905.

${ }^{18}$ See supra note 16 and accompanying text.
} 
infra, a similar analysis applies - and the result the Kovacik court reaches is, in general, internally inconsistent-where Kovacik's obligation is one to meet the firm's cash-flow obligations, up to $\$ 10,000$. So, for ease of exposition, this essay assumes in this Part that Kovacik agreed to make a specified contribution of $\$ 10,000$.

As to Reed, his agreement to provide services does not result in an accretion his capital account. That is because section 18(a) of the U.P.A., which somewhat indirectly sets forth the principles governing capital accounting, indicates that, on dissolution each partner is, in addition to receiving his share of profits or losses, "repaid his contributions, whether by way of capital or advances to the partnership property."19 Reed's capital account is not increased by a promise to provide services because the provision of a service is not an advancement of property.

So, we can show the firm having capital accounts equal to its total assets, Kovacik's contribution of (or obligation to contribute) $\$ 10,000$. The sum of the partners' individual capital accounts equals the firm's net worth.

For purposes of capital accounting-to implement section 18 of the U.P.A.-each partner's capital account is increased by $(w)$ his share of profits and $(x)$ his capital contributions and decreased by $(y)$ his withdrawals from the partnership and $(z)$ his share of partnership losses. ${ }^{20}$

We do not know the timing of the expenditures and revenues of the partnership. But, fortunately, preparation of the final capital accounts does not require us to know that. We know the partnership ultimately lost $\$ 8,680$. Thus, at the end of the partnership's operations, it now has net assets of $\$ 1,320$ (its net assets when it began business, $\$ 10,000$, minus its losses, or $\$ 10,000-\$ 8,680$ ).

${ }^{19}$ See, e.g., Cal. Corporations Code $\S 15018$ (a) (West 1955), repealed, 1996 Cal. Stat. 5905.

${ }^{20}$ Capital accounting in the R.U.P.A. is based on the following provision:

(a) Each partner is deemed to have an account that is:

(1) credited with an amount equal to the money plus the value of any other property, net of the amount of any liabilities, the partner contributes to the partnership and the partner's share of the partnership profits; and

(2) charged with an amount equal to the money plus the value of any other property, net of the amount of any liabilities, distributed by the partnership to the partner and the partner's share of the partnership losses.

R.U.P.A. $\S 401$ (Westlaw through 2004). As a textual matter, the U.P.A. does not, as the R.U.P.A. does, formally define a capital account in this way. See J. DENNIS HYNES \& Mark J. Loewenstein, Agency, Partnership and the LlC: The Law of UNINCORPORATED BUSINESS ENTERPRISES 638 ( $7^{\text {th }}$ ed. 2007). However, as the comments to this section note, "Section 401 is drawn substantially from U.P.A. Section 18," R.U.P.A. $\S 401$, cmt. 1, and the two Acts would provide for the same additions to and deductions from a capital account. 
The U.P.A. provides that, unless the parties agreed otherwise, losses are shared equally. ${ }^{21}$ There was not such an agreement. So, each partner's capital account will be decreased by one-half the losses, or $\$ 4,340$. That reduces Kovacik's capital account to $\$ 5,660(\$ 10,000-\$ 4,340)$, and Reed's capital account to $-\$ 4,340(\$ 0-\$ 4,340)$. Thus, when the business is to be wound-up, the parties' capital accounts look like this:

\section{Figure 2: Capital Accounts before Final Distributions}

$\begin{array}{lc}\text { Kovacik } & \$ 5,660 \\ \text { Reed } & (\$ 4,340) \\ \text { Total } & \$ 1,320\end{array}$

The firm's assets are $\$ 1,320$ at the time. Now, we don't know whether Kovacik actually contributed all the $\$ 10,000$ he promised to contribute. Let's say he only contributed $\$ 9,000$. For our purposes, it is sufficient to say that would mean the partnership has assets of $\$ 320$ on-hand, plus the right to an additional $\$ 1,000$ contribution from Kovacik. As a formal matter, the right to receive the additional $\$ 1,000$ might not be treated as an asset for capital accounting purposes, which would cause a corresponding decrease in Kovacik's capital account of $\$ 1,000 .^{22}$ The choice of that treatment or the treatment reflected in Figure 2 does not account for the discrepancy in the capital accounting treatment and the actual result in Kovacik. For ease of exposition, the single treatment referenced in Figure 2 is discussed here.

To wind up the partnership in accordance with the rules provided by U.PA. $\S 18(a)$, each partner having a positive value in his capital account should receive property of that total value, and each partner having a negative balance in his capital account needs to contribute that amount to the partnership. So, the capital accounting called-for by the U.P.A. provides that Reed needs to contribute $\$ 4,340$. The intermediate appellate court provided the answer the literal terms of the U.P.A. provide. ${ }^{23}$ The California Supreme Court did not. ${ }^{24}$

Before turning to why the language of the California Supreme Court's opinion is inconsistent, we need to recognize one inherent aspect of the capital accounting. At the time property is to be distributed, the sum of the

\footnotetext{
${ }^{21}$ See, e.g., Cal. Corporations Code $\S 15018$ (a) (West 1955), repealed, 1996 Cal. Stat. 5905.

${ }^{22}$ In that case, once the $\$ 1,000$ was contributed, the contribution would increase Kovacik's capital account. In the treatment reflected in Figure 2, the delivery of $\$ 1,000$ would not change the capital account; it would merely represent payment of a debt owing the partnership.

${ }^{23}$ See supra note 20 and accompanying text.

${ }^{24}$ See supra note 20 and accompanying text.
} 
parties' capital accounts has to equal the firm's net assets to be distributed. It is tautological. Recognition of this tautology is part of illuminating why the California Supreme Court's opinion is internally inconsistent.

\section{B. Services as Property; the Valuation Necessary to Support the Kovacik Result}

The California Supreme Court, in justifying its outcome, articulates the following view:

[T]he parties have, by their agreement to share equally in profits, agreed that the value of their contributions - the money on the one hand and the labor on the other-were likewise equal; it would follow that upon the loss, as here, of both money and labor, the parties have shared equally in the losses. Actually, of course, plaintiff here lost only some $\$ 8,680$ - or somewhat less than the $\$ 10,000$ he originally proposed and agreed to invest. ${ }^{25}$

Although California adopted the U.P.A. in 1929, the California Supreme Court's opinion is unhinged from the statutory language. The opinion does not expressly go through the steps of showing how statutory provisions would treat such an agreement. ${ }^{26}$ Framing the court's discussion in terms of the statutory language therefore requires making some inferences.

Section 18 of the U.P.A., in its introductory language, indicates that the distribution rules of section 18(a) can be changed by agreement among the parties. ${ }^{27}$ So, the provision that contributions of services do not result in accretions to a partner's capital account can be changed by agreement. It appears that the opinion, by this quoted language, concludes that the parties are implicitly agreeing in this context that the contribution of services will be treated as a capital contribution for capital accounting purposes. However, the court's failure to detail the application of this broad standard to the actual statutory provisions obscures problems with the view the court expresses. The problem becomes clear by looking at the capital accounts on formation and at winding-up.

If there were such an agreement that Reed's services were to be considered contributions to capital and that he had agreed to provide services valued equally with the property Kovacik contributed, the parties'

\footnotetext{
${ }^{25}$ Kovacik, 315 P.2d at 316.

${ }^{26} 1929$ Cal. Stat. 1896. Sections 18 and 40 of the U.P.A. were codified in California at that time at Cal. Corporations Code $\S \S 15018,15040$ (West 1955), repealed, 1996 Cal. Stat. 5905.

${ }^{27}$ See, e.g., Cal. Corporations Code $\S 15018$ (West 1955), repealed, 1996 Cal. Stat. 5905.
} 
capital accounts at the time the partnership was formed would have been as follows:

\section{Figure 3: Initial Capital Accounts if Reed's Services Valued Equally}

$\begin{array}{ll}\text { Kovacik } & \$ 10,000 \\ \text { Reed } & \$ 10,000 \\ \text { Total } & \$ 20,000\end{array}$

Above it was noted that the sum of the parties' capital accounts must equal the net assets to be distributed. This is where that understanding comes into play. For capital accounting purposes, if we say that services are counted as contributions, the partnership's losses during business for capital accounting purposes are increased, relative to the losses that were understood to have arisen when the firm did not treat the services as capital contributions.

We know that the firm ends up with $\$ 1,320$ in cash, after having received $\$ 10,000$ in cash capital contribution. The capital accounting cannot change that. However, for purposes of capital accounting, if it ends up with $\$ 1,320$ in net assets and has had initial contributions of $\$ 20,000$, that means, for capital accounting purposes, the firm has lost $\$ 18,680$ $(\$ 20,000-\$ 1,320)$. In order to have a value of $\$ 1,320$ when it is wound-up, it has "spent" both the $\$ 10,000$ initial capital contribution as well as the $\$ 10,000$ of Reed's services. Thus, the capital accounting when the partnership is wound-up looks like the following:

\section{Figure 4: Final Capital Accounts if Reed's Services Valued Equally}

Kovacik

$$
\begin{array}{lc}
\text { property contribution } & \$ 10,000 \\
\text { share of loss } & (\$ 9,340)
\end{array}
$$

Total

$\$ 660$

Reed

$\begin{array}{ll}\text { services contribution } & \$ 10,000 \\ \text { share of loss } & (\$ 9,340)\end{array}$

Total

Total

Treating Reed's services as a capital contribution, for purposes of section $18(\mathrm{a})$ of the U.P.A., valued at $\$ 10,000$ would require that, on 
dissolution, Reed would get $\$ 660$ from the partnership. ${ }^{28}$ To be clear, not only would Reed owe nothing, but he would, in fact, get something back.

One might wonder what value must be ascribed to Reed's promise to provide services in order to have Reed owe nothing and get back nothing. The answer is $\$ 8,680$. It is not a coincidence-a product of a fortuitous choice of numbers in this case-that this is the amount that the partnership lost on a cash (actual) basis. We would get a comparable result with different numbers. The detail of the analysis follows.

If Reed's services are valued at $\$ 8,680$, the firm's initial contributions are valued at $\$ 18,680$. The firm has net assets of $\$ 1,320$ on liquidation. So, the firm has a loss, for capital account purposes, of $\$ 17,360(\$ 18,680$ $\$ 1,320$ ), or $\$ 8,680$ each. The computations comparable to those in Figure 4 are:

Figure 5: Final Capital Accounts if Reed's Services Valued at the Amount of the Cash Loss Actually Incurred

Kovacik

$\begin{array}{ll}\text { property contribution } & \$ 10,000 \\ \text { share of loss } & (\$ 8,680)\end{array}$

Total

$\$ 1,320$

Reed

services contribution

share of loss

$\underline{(\$ 8,680)}$

Total

Total

C. The Inconsistency of the Kovacik Opinion; Indeterminacy of the Majoritarian Hypothetial Bargain

The introduction states the opinion is internally inconsistent. Now we can see why. At one point it references the parties as having silently agreed that the contributions to capital provided by each is of the same amount. ${ }^{29}$ Figure 4 shows that if that were the agreement the parties had entered into, Reed would be owed $\$ 660$ - which is not the result the court reaches.

This analysis also provides an argument for rejecting the Kovacik result that is not apparent unless one has gone through the arithmetic of the capital accounts. It is common to fill-in gaps in contractual obligations by

\footnotetext{
${ }^{28}$ Bainbridge notes, "Some students argue that the U.P.A. results in a windfall by the capital partner." Bainbridge, supra note 2, at 655 . He does not detail the theory underlying these concerns.

${ }^{29}$ See supra text accompanying note 25
} 
trying to figure out what parties would have agreed-upon had the matter been expressly discussed. ${ }^{30}$ One might make the following argument:

A court should ascertain what the majoritarian hypothetical bargain is. One can easily imagine the parties, at the time the contract was formed, having agreed that the value of Reed's promise to provide services was equivalent to Kovacik's promise to provide cash. Otherwise, why would the parties have split profits equally? If that's what the parties are considered to have agreed-to, and to have Reed's contribution of services be treated as a contribution to capital, Reed is owed $\$ 660$.

One cannot, on the other hand envision parties having, at the time the partnership was formed, agreed that Reed's agreement to provide services should be valued at the amount of the cash loss that the partnership will sustain over the course of its operation. That's the value that needs to be set if Reed owes nothing and Kovacik keeps all the remaining property. But there is not a good reason why the parties would have agreed to that valuation. It is not related to anything one can envision the parties thinking about when the partnership was formed.

There is an important level of generality in the hypothetical bargain that may be overlooked. The discussion in this essay frames the question as the hypothetical bargain between the parties concerning the relative values of their capital contribution. It does that because the statutory provisions cause the issue to be framed in that way. The U.P.A. provides for a repayment of capital contributions in liquidation. It is by deeming services a contribution to capital that one can harmonize the Kovacik result with the statute. So, the U.P.A. focuses the analysis on how to fit the contribution of services within that framework.

There is, of course, another way to look at the issue-what the parties would have bargained-for as to the ultimate result in this context. The level of generality at which one asks the question can matter substantially.

Bainbridge provides a lengthy discussion of the majoritarian hypothetical bargain of parties in this context. He identifies as the most likely candidates:

- All capital losses were to be borne by the capital partner alone (Kovacik).

- Sharing of capital losses in accordance with sharing of profits (statute).

${ }^{30}$ See, e.g., Taylor v. Caldwell, (1863) 122 Eng. Rep. 309, 312 (K.B.) (stating, in discussing the impact of the destruction of a music hall on contract calling for making it available for use, "There seems little doubt that this implication tends to further the great object of making the legal construction such as to fulfill the intention of those who entered into the contract. For in the course of affairs men in making such contracts in general would, if it were brought to their minds, say that there should be such a condition."). 
- If the service-only partner has made a nominal capital contribution, allocate capital losses according to the ratio of capital contributions. ${ }^{31}$

As Bainbridge notes, because the partner providing services most likely has less capital than the other partner, it might seem natural to allocate the risk of a loss to the party who is better able to bear the lossthe party who has capital. ${ }^{32}$ The result in Kovacik is consistent. Yet, Sher and Bromberg noted fifty years ago an economic factor that undercuts the power of the rationale of the Kovacik rule to predict the majoritarian hypothetical bargain: "The reasoning is specious if value is gauged by future earning power: that of [the property-contributing partner's] asset is lost with the asset, that of the [services partner's] labor continues as a personal capacity.",33

Bainbridge additionally provides a thoughtful observation that would militate against the Kovacik result being the majoritarian hypothetical bargain. He notes the Kovacik approach creates incentives for the services partner, who by postulate will be the partner more involved in the day-today operations, to cause the firm to engage in excessive risk-taking. ${ }^{34}$ One might view the point as an extreme application of the overinvestment problem identified in Jensen and Meckling's seminal work. ${ }^{35}$ In light of the competing factors, Bainbridge ultimately concludes, "In sum, there does not appear to be a determinate majoritarian outcome to the hypothetical bargain in this context." 36

This case illustrates an inherent difficulty in seeking to apply the hypothetical bargain standard-the level of generality to be used is not obvious. $^{37}$ Would one use the majoritarian outcome for all service partnerships, for service partnerships in the particular field? Perhaps in some fields, e.g., a partnership involved in debt collection where the services partner is a lawyer-one would have different a priori assessments of the likelihood of opportunistic behavior. The likelihood that the services partner would engage in strategic misbehavior might be related to the services partners being more likely to be lawyers-one's view of the impact, positive or negative, could perhaps be subject to disagreement. Would one use the majoritarian outcome for persons who trusted each other

\footnotetext{
${ }^{31}$ Bainbridge, supra note 2, at 648-49.

${ }^{32}$ Id. at 649.

${ }^{33}$ Byron D. Sher \& Alan R. Bromberg, Texas Partnership Law in the $20^{\text {th }}$ CenturyWhy Texas Should Adopt the Uniform Partnership Act, 12 Sw. L. J. 263, 290 (1958).

${ }^{34}$ Bainbridge, supra note 2, at 650, 662-65.

${ }^{35}$ Michael C. Jensen \& William H. Meckling, Theory of the Firm: Managerial Behavior, Agency Costs and Ownership Structure, 3 J. FIN. ECON. 305, 334 (1976).

${ }^{36}$ Bainbridge, supra note 2, at 659.

${ }^{37}$ See generally Royce de R. Barondes, The Limits of Quantitative Legal Analyses: Chaos in Legal Scholarship and FDIC v. W.R. Grace \& Co., 48 RUTGERS L. REV. 161, 204 (1995) ("[T] with respect to both the parties and the transaction.").
} 
at the time the partnership was formed, if there is proof of that matter in a particular case?

Although choosing the proper level of generality may be difficult in many cases, it would seem appropriate to peg the level of generality on the statutory language where there is a statute that actually has pertinent language. The statutory provisions create the rules capital accounting implements. It is more consistent with the role of a court where there is, in fact, a pertinent statutory provision to try to apply the statutory provision. That would call for framing the question in light of the structure the statute provides. In this case, doing so calls for a relatively focused level of generality-what the parties would have agreed-upon as the relative values of their contributions.

\section{How the Kovacik Result CAN MAKe the Services Partner MORE RISK-AVERSE}

As noted above, Bainbridge makes the thoughtful observation that the Kovacik result can create increased incentives for risk-taking by the services partner in management of the partnership. On the other hand, it is possible that it might make a services partner more risk-averse in making decisions. Again, illustration of the principle requires reference to the actual numbers.

This alternative incentive involves how a services partner would value potential outcomes in circumstances not precisely like that the Kovacik court faced. So, before turning to the capital accounting, we must see how a court would treat a circumstance somewhat different from that at issue in Kovacik.

Kovacik's capital contribution was capped at $\$ 10,000$ - the opinion refers to "the $\$ 10,000$ which [Kovacik] originally proposed and agreed to invest." 38 To understand the services partner's full incentives, we need to know what happens if the partnership loses, on a cash basis, more than $\$ 10,000$. The firm could, of course, lose more than was originally invested. That Kovacik "provided all of the venture's financing through the credit of Asbestos Siding Company"39 may identify-perhaps more clearly today than in the 1950 s-one circumstance in which a remodeling firm, like this partnership, could end up with liabilities in excess of the cash needed initially to perform remodeling services.

If the partnership lost more than the cash Kovacik agreed to provide as capital, the court could allocate that additional loss in whole to Kovacik or equally between the parties. Let us assume the court, had it been faced with that question, would have allocated the additional loss equally between the

\footnotetext{
${ }^{38}$ Kovacik, 315 P.2d at 316.

${ }^{39} I d$. at 315.
} 
parties. ${ }^{40}$ This view is not unreasonable. Allocating all losses to Kovacik would effectively eliminate the significance of the expressly articulated $\$ 10,000$ cap on his contribution obligation.

Under this view, the services partner can have incentives to take less risk than is desirable for the firm as a whole. Consider the following example: Kovacik has contributed $\$ 10,000$. The firm has operated at a loss of $\$ 7,500$ on a cash basis. The firm is considering either doing no more business or undertaking a project with the following payoff structure:

- $50 \%$ - makes $\$ 7,000$ on a cash basis, giving it a net cash loss of $\$ 500(-\$ 7,500+\$ 7,000)$

- $50 \%$ - loses $\$ 5,000$ on a cash basis, giving it a net cash loss of $\$ 12,500(-\$ 7,500-\$ 5,000)$

The expected value of this project is $\$ 1,000$. So, at least on a cash basis, it is in the aggregate best interest of the firm to undertake the project. ${ }^{41}$ However, as illustrated in Figure 6, it is a money-loser for Reed. That is because if the firm loses an additional $\$ 5,000$, the firm will have lost a total of $\$ 12,500$. Kovacik is responsible for the first $\$ 10,000$, but the remaining $\$ 2,500$ loss is split evenly. That makes Reed liable for $\$ 1,250$ in that case, with Kovacik having lost $\$ 11,250$. If the firm makes $\$ 7,000$, the firm will have made up almost all its prior loss, with a total loss of only $\$ 500$. So the results are:

Figure 6: Illustrating Increased Risk-Aversion Under Kovacik

$\begin{array}{llll}\begin{array}{lll}\text { Do Nothing } \\ \text { New Project }\end{array} & \underline{\text { Firm }} & \underline{\text { Kovacik }} & \underline{\text { Reed }} \\ \text { Success-50\% likekihood } & -\$ 7,500 & -\$ 7,500 & \$ 0 \\ \text { Failure-50\% likekihood } & -\$ 500 & -\$ 500 & \$ 0 \\ \text { Expected Value } & \underline{-\$ 12,500} & \underline{-\$ 11,250} & \underline{-\$ 1,250} \\ & -\$ 6,500 & -\$ 5,875 & -\$ 625\end{array}$

The expected aggregate value of the firm's operations if it undertakes the new project is $-\$ 6,500, \$ 1,000$ higher than the value before doing the

\footnotetext{
${ }^{40}$ Sher and Bromberg reference the following theory, which they call the labor theory: " $Y$ [the services partner] then has the additional argument that his labor counterbalances $X$ 's assets as a contribution to the partnership; $Y$ suffers the loss of his labor just as much as $X$ suffers the loss of his assets; therefore neither should contribute to the other's loss." Sher \& Bromberg, supra note 33, at 289-90. This theory is comparable to part of the rationale expressed in Kovacik. See supra note 25 and accompanying text. As Sher and Bromberg note, "This theory affords no guidance if the loss exceeds $X$ "s asset contribution." Id. at 290.

${ }^{41}$ We are now attributing no cost to Reed's services in this new project. That simply makes the description of the circumstance easier; it's not required to illustrate the point.
} 
new project. It is in the aggregate best interest of the firm to undertake the project. However, it is a money loser for Reed. In sum, under this scenario, Reed is more risk-averse than the firm as a whole. This creates incentives for Reed to use his influence as the services partner to avoid having the partnership undertake this particular project, perhaps by overestimating its risks to Kovacik or by some other method.

One of the basic differences between a partnership and a corporation is that, absent an agreement to the contrary, each owner of a partnership has the right to compel the termination of the business. ${ }^{42}$ Thus, the impact of these incentives may be mitigated in a partnership relative to a corporation, ${ }^{43}$ to the extent the partner providing cash is fully informed.

The point being made here is not that there will, in fact, generally be less risk-taking. Rather, the point is that there are incentives to avoid risk as well as incentives Bainbridge identifies to take additional risk. This additional complexity makes it even more impracticable to try to ascertain what the majoritarian hypothetical bargain would have been, further supporting Bainbridge's conclusion that "[T]here does not appear to be a determinate majoritarian outcome to the hypothetical bargain in this context."

\section{MORE COMPLEX ILLUSTRATION- OBLIGATION TO MEET CASH-FLOW REQUIREMENTS}

This essay's initial analysis of Kovacik construed Kovacik's obligation as requiring Kovacik contribute $\$ 10,000$ - to meet cash-flow obligations. Kovacik's undertaking could have been of a different form. This Part analyzes that circumstance.

Kovacik could have undertaken to make cash contributions to the extent required to meet the partnership's cash-flow obligations, up to $\$ 10,000$. Treating the parties' contributions of equal value and as contributions to the "property" of the partnership will not necessarily produce the result the court reached.

To analyze this circumstance, one will have to know the cash-flow requirements of the business. Let us assume, for the moment, that the partnership had cash needs of $\$ 1,000$ per month, and the endeavor was finished in 10 months. Also assume no profit or loss is realized until the very end of the business venture. The capital accounts at the end of the first

\footnotetext{
${ }^{42}$ See U.P.A. $\$ \S 31(1)$ (b) (dissolution caused by express will of any partner), 38(1) (on dissolution, each partner "may have partnership property applied to discharge its liabilities, and the surplus applied to pay in cash the net amount owing to the respective partners").

${ }^{43}$ Of course, were a corporation operating in default under a credit agreement, its creditors, if fully informed, would also have a right to immediate exit.

${ }^{44}$ Bainbridge, supra note 2, at 659 .
} 
month, treating services of equal value as the cash contributions, would have been:

Figure 7: Capital Accounts After One Month

$\begin{array}{lr}\text { Kovacik } & \$ 1,000 \\ \text { Reed } & 1,000 \\ \text { Total } & \$ 2,000\end{array}$

This discussion has skirted a somewhat thorny issue. The requirements for capital from Kovacik and services from Reed need not be simultaneous. Consider, for example, the case in which $\$ 1,000$ in cash is needed immediately upon formation of the business, and Reed provides daily service for each day in the month. Would one say that, after the first day, Reed's services had a value of Kovacik's contribution? If so, that would mean that his services for the remainder of the month had no value. We will, however, elide that granularity in the supposed agreement.

After the second month, the capital accounts would have been:

Figure 8: Capital Accounts After Two Months

$\begin{array}{lr}\text { Kovacik } & \$ 2,000 \\ \text { Reed } & 2,000 \\ \text { Total } & \$ 4,000\end{array}$

After the tenth month, the capital accounts would have been:

Figure 9: Capital Accounts After Ten Months

$\begin{array}{lr}\text { Kovacik } & \$ 10,000 \\ \text { Reed } & \underline{10,000} \\ \text { Total } & \$ 20,000\end{array}$

This is identical to the circumstance illustrated in Figures 3 and 4 . If the firm now liquidates, treating the parties as if they had agreed to treat Reed's services as capital contributions of an equal value to Kovacik's cash contributions, following the statutory provisions of the U.P.A. requires each party gets back $\$ 660$. The result is different, but still not the result the court reached in Kovacik, if Kovacik contributed only $\$ 9,000$. The capital accounts are as follows at the end of the ninth month, before the loss is realized: 
Figure 10: Capital Accounts After Nine Months

\begin{tabular}{lr} 
Kovacik & $\$ 9,000$ \\
Reed & $\underline{9,000}$ \\
Total & $\$ 18,000$ \\
\hline
\end{tabular}

If it liquidates now, after nine months, the firm still has a loss, on a cash basis, of $\$ 8,680$. The cash initially contributed was $\$ 9,000$. That means the firm has assets remaining of $\$ 9,000-\$ 8,680$, or $\$ 320$. For our capital accounting purposes, the loss is $\$ 18,000-\$ 320$, or $\$ 17,680$. Each partner's share of the loss is half that, or $\$ 8,840$. So, at the time the partnership is to be wound-up, the capital accounts are:

Figure 11: Final Capital Accounts if Reed's Services Valued Equally-$\$ \mathbf{\$ 9 0 0}$ Capital Contribution

Kovacik

$$
\begin{array}{lc}
\text { property contribution } & \$ 9,000 \\
\text { share of loss } & (\$ 8,840) \\
\hline
\end{array}
$$

Total

$\$ 160$

Reed

services contribution

$\$ 9,000$

share of loss

$(\$ 8,840)$

Total

Total

$\$ 320$

The result is still inconsistent with Kovacik. Reed is entitled to a cash distribution-but in a smaller amount, $\$ 160$. As one might surmise, if the amount that Kovacik is required to contribute to fund the partnership - its cash-flow requirements-is $\$ 8,680$, the loss on a cash basis, Reed gets back nothing.

This result arises because Kovacik's obligation is here being measured based on the partnership's cash-flow requirements. A firm's cash-flow needs are not necessarily the same as the amount of its loss on a cash basis.

\section{CONCLUSION}

The opinion in Kovacik v. Reed, although purporting to rationalize its outcome in two different ways, in fact-apparently without the knowledge of the opinion's author-supports two different rules. The Kovacik court purports to reach its conclusion by referencing essentially an implicit agreement as to the relative values of their capital contributions. However, the statutory provisions of the U.P.A. require a different implicit bargain as 
to the relative values of the parties' contributions in order to reach the result the Kovacik court reaches. That implicit agreement is the following: The value of the services provided by the services partner had an agreed value of the amount the partnership would ultimately lose (on a cash basis). Under this implicit bargain, the more the firm lost, the more valuable the services were. A rationale for such a bargain is elusive.

Kovacik also illuminates an inherent difficulty with trying to formulate a hypothetical bargain solution. The level of generality used to determine the hypothetical bargain can substantially change the results.

The more obvious issue in assessing that level of generality is the extent to which the parties' and the transaction's attributes are incorporated. Kovacik illustrates a different dimension in selecting the level of generality to assess the hypothetical bargain. If the matter is governed by statute, there may be difficult questions concerning how to frame the hypothetical bargain. It may be framed in terms of how the parties would have wanted the outcome to be settled. Or, as in a case with facts similar to Kovacik, it may be framed in terms of how the parties would have resolved the question that the statutory provision treats as dispositive. This choice of reference frame, as an analysis of Kovacik shows, may substantially influence the outcome. 
